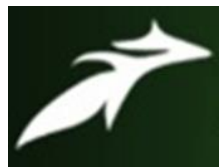

MOHAMMAD MONIS ANSARI et al, International Journal of Advances in Agricultural Science and Technology,

Vol.7 Issue.12, December-2020, pg. 21-28

ISSN: 2348-1358

Impact Factor: 6.057

NAAS Rating: 3.77

\title{
Knowledge of the Guava Growers about Recommended Production Practices in Kaurihar, District of Prayagraj (Allahabad), Uttar Pradesh
}

\author{
MOHAMMAD MONIS ANSARI ${ }^{1 *}$; DIPAK K. BOSE ${ }^{2}$; SYED H. MAZHAR ${ }^{3}$ \\ Department of Agricultural Extension \& Communication, Naini Agriculture Institute, Sam Higginbottom \\ University of Agriculture, Technology and Sciences, Prayagraj (Allahabad)-211007 (Uttar Pradesh) \\ ${ }^{1}$ P.G. Student* (monis.rj26@gmail.com); ${ }^{2}$ Associate Professor; ${ }^{3}$ Associate Professor
}

DOI: 10.47856/ijaast.2020.v07i12.004

\begin{abstract}
The research was conducted in Kaurihar block of Prayagraj district of U.P. The purpose of the study was to assist the Socio-economic profile of the guava growers and the knowledge regarding the recommended guava production practices. Kaurihar block was purposely selected because of the maximum production. 20 villages were randomly selected from the block, 120 respondents were selected 6 from the each village. The results shows that majority 49.17 per cent of the respondent belongs to Low Level of Socio Economic Status, followed by 44.17 per cent and 06.66 per cent respondents belongs to Medium and High Level of Socio Economic Status respectively. Majority 67.50 per cent of the respondent has Medium Level of Knowledge, followed by 26.67 per cent respondents has Low Level of Knowledge, and remaining 5.83 per cent of respondents has High Level of Knowledge. Majority of the respondents were from Medium level of Progressiveness, Medium level of Risk bearing Capacity and Low socio-economic status, the respondents were having high knowledge in Improved Variety, Packaging of produce and Marketing, Medium knowledge in Intercropping, High Density planting, Propagation method, Row-Row \& Plant-plant distance, NPK ratio, Irrigation, Major Disease, Insect Pest and Pruning of plant, Low knowledge about Bahar treatment, Disease Control, Insecticides, Mulching, Training of Plant and Post-Harvest. Correlation between Socio-economic profile and Knowledge of guava cultivation Risk bearing Capacity 0.899, Progressiveness 0.889 and Source of Information 0.792, shows Strong positive correlation.
\end{abstract}

KEYWORDS: Socio-economic, Knowledge, Recommended Practices, Correlation, Guava.

\section{INTRODUCTION}

India is the fruit and vegetable basket of the world. India being a home of wide variety of fruits and vegetables holds a unique position in production figures among other countries. Over $90 \%$ of India's exports in fresh products go to W. Asia and E. European markets. However, it needs to augment its food processing industry at a mega scale. The covered area under the fresh fruits in India is 65.06 lakh ha with the production of 973.58 lakh MT in 2017-18. The major fruits grown in India are Banana, Mango, Citrus, Papaya, Guava, Water Melons, Litchi and Apple etc. (Horticultural Statistics at a Glance 2018). Uttar Pradesh is the $3^{\text {rd }}$ largest producer of the fresh fruits in the country, after Andhra Pradesh and Maharashtra. Uttar Pradesh Produces 105.40 lakh 


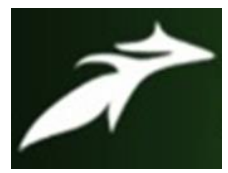

MOHAMMAD MONIS ANSARI et al, International Journal of Advances in Agricultural Science and Technology, Vol.7 Issue.12, December-2020, pg. 21-28

ISSN: 2348-1358

Impact Factor: 6.057

NAAS Rating: 3.77

MT which is approximately $10.82 \%$ falling short to Andhra Pradesh that produces 152.16 lakh MT fresh fruit (15.63\%) and Maharashtra contributing its share of 117.29 lakh MT (12.05\%) (Horticultural Statistics at a Glance 2018)Guava (Psidiumguajava L.) belongs to the Myrtacea family and most commercially important fruit of the family Myrtacea, popularly known as the "Apple of Tropics". In India Guava is so popular that it's hard to believe the fruit is not native to our country. It originates in tropical America along with a number of other fruits and appears to have grown from Mexico to Peru. As stated by Burton who was in India at the beginning of $17^{\text {th }}$ century, it is thought to be introduced in India at a very early point.Some important varieties of Guava includes; Allahabadi Safeda, the fruits of Allahabadi Safeda are round in shape and the skin is smooth, the flesh is white, soft and has a pleasant flavor. Lucknow 49 is large, roundish in shape and pulp is white, very sweet and tasty. Allahabadi Surkha \& Chittidar is a variety with uniform pink fruit with deep pink flesh.Guava is rich source of vitamin - C and pectin, $250 \mathrm{gm}$ vitamin $\mathrm{C} / 100 \mathrm{~g}$ of fruit, which differ with the variety, stage of maturity and season. It is a good source of both thiamine and riboflavin. Its fruits have good taste, nourishing value and a lot of minerals. It ranks third in vitamin $\mathrm{C}$ content after Barbados cherry and anola. The fruits are consumed as fresh as well as used for manufacturing jam, jelly and other processed product. Guava jelly is well known to all and the common sour wild guava makes the best jelly. With keeping the above detail in background, the present study was conducted at the Kaurihar block of Prayagraj district of U.P during the year 2019 with objective of knowledge of recommended guava production practices.

The study was conducted Based on the analysis, it may be inferred that cultivation of guava in Prayagraj is economically viable, not only for the farmers, but also for the entrepreneurs who would like to grow guava on commercial basis. However, other added advantages like higher potential of employment generation, additional return that can be realized by introducing vegetables as intercrops have not been taken into consideration while estimating economic return which could have otherwise strengthen the economic viability of guava cultivation.

\section{RESEARCH METHODOLOGY}

Prayagraj district was purposely selected for present study because guava being major fruit for the area. Kaurihar block was purposely selected because of its maximum area under Guava. 20 villages were selected purposely on the basis of maximum area under Guava cultivation.From each selected village 6 respondents were selected randomly Thus total of 120 respondents were selected for present study. The primary data was collected with the help of personal interview technique with the help of pre-structured interview schedule designed especially in the light of 


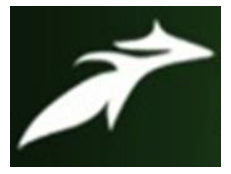

MOHAMMAD MONIS ANSARI et al, International Journal of Advances in Agricultural Science and Technology, Vol.7 Issue.12, December-2020, pg. 21-28

ISSN: 2348-1358

Impact Factor: 6.057

NAAS Rating: 3.77

objectives set up for the study.Secondary data was collected from books, journal, library, documents and government websites etc.

The dependent variable in the context of the present study was knowledge of recommended guava production practices. The selected independent variables were grouped on the basis of socio-economic, socio-psychological and extension communication characteristics. The acceptability of an innovation to an individual depends on its permissibility to his socioeconomic and psychological orientation. Thus in the present study, the selection of independent variables were made to include following characters under socioeconomic, socio-psychological nature, age, education, land holding, Annual income, family size, social participation, extension contact, source of information, progressiveness, risk bearing capacity.

Person's Correlation statistical test was applied as per the nature of the data. The collected data was transformed into score for tabulation and analysis in the light of objectives to draw the logical conclusion.

\section{RESULTS AND DISCUSSION}

Result and discussion deal with frequency, percentage, average, distribution of various economic and psychological characteristics of the guava grower as well as the correlation of scientific guava cultivation with the knowledge of growers.

Table-1: Socio Economic Profile of the respondents.

\begin{tabular}{|c|c|c|c|c|}
\hline S.N & \multicolumn{2}{|c|}{ Socio-economic Profile } & Frequency & Percentage \\
\hline \multirow[t]{3}{*}{1.} & \multirow[t]{3}{*}{ Age } & Young (20-35) & 11 & 09.17 \\
\hline & & Middle (36-55) & 63 & 52.50 \\
\hline & & Old $\quad(>56)$ & 46 & 38.33 \\
\hline \multirow[t]{6}{*}{2.} & \multirow[t]{6}{*}{ Education } & Illiterate & 68 & 56.67 \\
\hline & & Primary & 25 & 20.83 \\
\hline & & Junior H.S & 08 & 06.66 \\
\hline & & High School & 14 & 11.67 \\
\hline & & Intermediate & 03 & 02.50 \\
\hline & & Graduate \& above & 02 & 01.67 \\
\hline \multirow[t]{3}{*}{3.} & \multirow[t]{3}{*}{ Land Holding } & $<1$ hectare & 65 & 54.17 \\
\hline & & 1-2 hectare & 43 & 35.83 \\
\hline & & $>2$ hectare & 12 & 10.00 \\
\hline & & & & \\
\hline
\end{tabular}




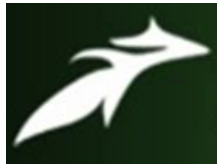

MOHAMMAD MONIS ANSARI et al, International Journal of Advances in Agricultural Science and Technology, Vol.7 Issue.12, December-2020, pg. 21-28

ISSN: 2348-1358

Impact Factor: 6.057

NAAS Rating: 3.77

\begin{tabular}{|c|c|c|c|c|}
\hline \multirow[t]{3}{*}{4.} & \multirow[t]{3}{*}{ Annual Income } & $<50,000$ & 56 & 46.67 \\
\hline & & $50,001-100,000$ & 49 & 40.83 \\
\hline & & $>100,000$ & 15 & 12.50 \\
\hline \multirow[t]{2}{*}{5.} & \multirow[t]{2}{*}{ Family Type } & Nuclear & 46 & 38.33 \\
\hline & & Joint & 74 & 61.67 \\
\hline \multirow[t]{3}{*}{6.} & \multirow[t]{3}{*}{ Social Participation } & No Membership & 60 & 50.00 \\
\hline & & Membership of 1 organization & 51 & 42.50 \\
\hline & & 2 or more Membership org. & 09 & 07.50 \\
\hline \multirow[t]{3}{*}{7.} & \multirow[t]{3}{*}{ Extension Contact } & Low & 60 & 50.00 \\
\hline & & Medium & 51 & 42.50 \\
\hline & & High & 09 & 07.50 \\
\hline \multirow[t]{3}{*}{8.} & \multirow{3}{*}{$\begin{array}{l}\text { Source of } \\
\text { Information }\end{array}$} & Low & 55 & 45.83 \\
\hline & & 55Medium & 58 & 48.84 \\
\hline & & High & 07 & 05.83 \\
\hline \multirow[t]{3}{*}{9.} & \multirow[t]{3}{*}{ Progressiveness } & Low & 19 & 15.83 \\
\hline & & Medium & 74 & 61.67 \\
\hline & & High & 27 & 22.50 \\
\hline \multirow[t]{3}{*}{10.} & \multirow{3}{*}{$\begin{array}{l}\text { Risk Bearing } \\
\text { Capacity }\end{array}$} & Low & 16 & 13.33 \\
\hline & & Medium & 80 & 66.67 \\
\hline & & High & 24 & 20.00 \\
\hline
\end{tabular}

Table-2: Over all Socio Economic Status of the respondents.

\begin{tabular}{|c|c|c|c|}
\hline S. $\mathbf{~}$ & Status & Frequency & Percentage \\
\hline $\mathbf{1 .}$ & Low & 59 & 49.17 \\
\hline $\mathbf{2 .}$ & Medium & 53 & 44.17 \\
\hline $\mathbf{3 .}$ & High & 08 & 06.66 \\
\hline $\mathbf{4 .}$ & Total & $\mathbf{1 2 0}$ & $\mathbf{1 0 0 . 0 0}$ \\
\hline
\end{tabular}

Above data indicates that majority 49.17 per cent of the respondent belongs to Low Level of Socio Economic Status, followed by 44.17 per cent and 06.66 per cent respondents belongs to Medium and High Level of Socio Economic Status respectively.

Table-3: Knowledge level of the respondents for Guava Production Practices.

\begin{tabular}{|c|l|c|c|c|}
\hline S.N & \multicolumn{1}{|c|}{ Particulars } & FC & PC & NC \\
\hline 1. & $\begin{array}{l}\text { Improved varieties (Alld. Surkha, Alld. Safeda, Chittidar } \\
\text { and Lalit) }\end{array}$ & $\begin{array}{c}80 \\
(66.67)\end{array}$ & $\begin{array}{c}40 \\
(33.33)\end{array}$ & $\begin{array}{c}00 \\
(00.00)\end{array}$ \\
\hline 2. & Bahar Treatment Ambe (feb), Hasta (oct) and Mrig (june) & 03 & 32 & 85 \\
& & $(02.50)$ & $(26.67)$ & $(70.83)$ \\
\hline
\end{tabular}




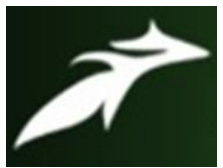

MOHAMMAD MONIS ANSARI et al, International Journal of Advances in Agricultural Science and Technology, Vol.7 Issue.12, December-2020, pg. 21-28

ISSN: 2348-1358

Impact Factor: 6.057

NAAS Rating: 3.77

\begin{tabular}{|c|c|c|c|c|}
\hline 3. & Intercropping in guava (peas, cowpea and gram) & $\begin{array}{c}05 \\
(04.17)\end{array}$ & $\begin{array}{c}72 \\
(60.00)\end{array}$ & $\begin{array}{c}43 \\
(35.83)\end{array}$ \\
\hline 4. & $\begin{array}{l}\text { Number of plant in High density guava orchard (5185 } \\
\text { plant/ha) }\end{array}$ & $\begin{array}{c}01 \\
(00.83)\end{array}$ & $\begin{array}{c}76 \\
(63.34)\end{array}$ & $\begin{array}{c}43 \\
(35.33)\end{array}$ \\
\hline 5. & $\begin{array}{l}\text { Propagation methods; seed, layering, air layering, grafting } \\
\text { (budding or grafting), cuttings (root or shoot) or tissue } \\
\text { culture. }\end{array}$ & $\begin{array}{c}42 \\
(35.00)\end{array}$ & $\begin{array}{c}76 \\
(63.34)\end{array}$ & $\begin{array}{c}02 \\
(01.67)\end{array}$ \\
\hline 6. & $\begin{array}{l}\text { Row to row \& Plant to plant distance } 2 \mathrm{~m} * 1 \mathrm{~m}(5000 \\
\text { plant/ha) }\end{array}$ & $\begin{array}{c}02 \\
(01.67)\end{array}$ & $\begin{array}{c}112 \\
(93.33)\end{array}$ & $\begin{array}{c}06 \\
(05.00)\end{array}$ \\
\hline 7. & $\begin{array}{l}\text { NPK ratio one kg each in two split doses during March and } \\
\text { October Farm yard manure @ } 50 \mathrm{~kg}\end{array}$ & $\begin{array}{c}08 \\
(06.67)\end{array}$ & $\begin{array}{c}105 \\
(87.50)\end{array}$ & $\begin{array}{c}07 \\
(05.83)\end{array}$ \\
\hline 8. & $\begin{array}{l}\text { Number of Irrigation @ interval of } 20-25 \text { days in winter, } \\
10-15 \text { days in summer }\end{array}$ & $\begin{array}{c}10 \\
(08.33)\end{array}$ & $\begin{array}{c}106 \\
(88.34)\end{array}$ & $\begin{array}{c}04 \\
(03.33)\end{array}$ \\
\hline 9. & $\begin{array}{l}\text { Major diseases: wilt, fruit canker, fruit rot, anthracnose and } \\
\text { grey leaf spot. }\end{array}$ & $\begin{array}{c}43 \\
(35.83)\end{array}$ & $\begin{array}{c}76 \\
(63.34)\end{array}$ & $\begin{array}{c}01 \\
(00.83)\end{array}$ \\
\hline 11. & $\begin{array}{l}\text { Control methods: Carbendazim/Thiophanate methyl (1g./l) } \\
\text { or Kavach/Mancozeb }(2 \mathrm{~g} / \mathrm{l})\end{array}$ & $\begin{array}{c}00 \\
(00.00)\end{array}$ & $\begin{array}{c}07 \\
(05.83)\end{array}$ & $\begin{array}{c}113 \\
(94.17)\end{array}$ \\
\hline 12. & $\begin{array}{l}\text { Major insect- pests: fruit fly, stem borer, bark eating } \\
\text { caterpillar, thrips, nematode, mealy bug, scale insect. }\end{array}$ & $\begin{array}{c}31 \\
(25.83)\end{array}$ & $\begin{array}{c}89 \\
(74.17)\end{array}$ & $\begin{array}{c}00 \\
(00.00)\end{array}$ \\
\hline 13. & $\begin{array}{l}\text { Control methods: Malathion ( } 2 \mathrm{ml} .), \text { Phosphamidon } \\
(0.5 \mathrm{ml} / \mathrm{ltr}) \text {, Dimethoate Monocrotophos. }\end{array}$ & $\begin{array}{c}00 \\
(00.00)\end{array}$ & $\begin{array}{c}05 \\
(04.17)\end{array}$ & $\begin{array}{c}115 \\
(95.83)\end{array}$ \\
\hline 14. & $\begin{array}{l}\text { Mulching: Black polyethylene sheet/Organic materials at } \\
\text { least twice a year. }\end{array}$ & $\begin{array}{c}04 \\
(03.33) \\
\end{array}$ & $\begin{array}{c}26 \\
(21.17) \\
\end{array}$ & $\begin{array}{c}90 \\
(75.00) \\
\end{array}$ \\
\hline 15. & $\begin{array}{l}\text { Training: clean trunk from } 60-90 \mathrm{~cm} \text { from the base, } \\
\text { building strong framework at young age. }\end{array}$ & $\begin{array}{c}03 \\
(02.50)\end{array}$ & $\begin{array}{c}12 \\
(10.00)\end{array}$ & $\begin{array}{c}105 \\
(87.50)\end{array}$ \\
\hline 16. & $\begin{array}{l}\text { Pruning: Removal of unwanted plant parts after harvesting } \\
\text { or in spring. }\end{array}$ & $\begin{array}{c}13 \\
(10.83)\end{array}$ & $\begin{array}{c}98 \\
(81.17)\end{array}$ & $\begin{array}{c}09 \\
(07.50)\end{array}$ \\
\hline 17. & $\begin{array}{l}\text { Packing of guava local made baskets and wooden or } \\
\text { corrugated fibre board boxes for distance market. }\end{array}$ & $\begin{array}{c}89 \\
(74.17)\end{array}$ & $\begin{array}{c}30 \\
(25.00)\end{array}$ & $\begin{array}{c}01 \\
(00.83)\end{array}$ \\
\hline 18. & Post-Harvest handling and value addition. (Jam\&Jelly etc.) & $\begin{array}{c}00 \\
(00.00)\end{array}$ & $\begin{array}{c}11 \\
(09.17)\end{array}$ & $\begin{array}{c}109 \\
(90.83)\end{array}$ \\
\hline
\end{tabular}

Above data shows that majority of the respondents has high knowledge in Improved Variety(66.67\%), Medium knowledge in Intercropping(60.00\%), High Density planting(63.34\%), Propagation method(63.34\%), Row-Row \& Plant-plant distance(93.33\%), NPK ratio(85.50\%), Irrigation management(88.34\%), Major Disease(63.34\%), Insect Pest(74.17\%) and Pruning of plant(81.17\%), Low knowledge about Bahar treatment(74.83), 


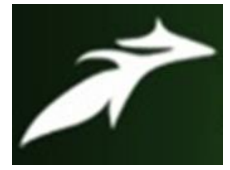

MOHAMMAD MONIS ANSARI et al, International Journal of Advances in Agricultural Science and Technology, Vol.7 Issue.12, December-2020, pg. 21-28

ISSN: 2348-1358

Impact Factor: 6.057

NAAS Rating: 3.77

Disease Control(94.17\%), Insecticides(95.83)\%, Mulching(75.00\%), Training of Plant(87.50\%) and Post-Harvest $(90.83 \%)$

Table-4: Overall knowledge of the respondents for Guava Production Practices.

\begin{tabular}{|c|c|c|c|}
\hline S. $\mathbf{N}$ & Status & Frequency & Percentage \\
\hline $\mathbf{1 .}$ & Low & 32 & 26.67 \\
\hline $\mathbf{2 .}$ & Medium & 81 & 67.50 \\
\hline $\mathbf{3 .}$ & High & 07 & 05.53 \\
\hline $\mathbf{4 .}$ & Total & $\mathbf{1 2 0}$ & $\mathbf{1 0 0 . 0 0}$ \\
\hline
\end{tabular}

Table-4 indicates that majority 67.50 per cent of the respondent has Medium Level of Knowledge, followed by 26.67 per cent respondents has Low Level of Knowledge, and remaining 5.83 per cent of respondents has High Level of Knowledge.

Table-5 indicates the distribution of the 10 independent variables in terms of their coefficient of variation and the ranks of their consistency also depicted.

Table-5: Descriptive distribution of the variables with reference to respondent profile:

Table-5 presents the distribution of the 10 independent variables in term of their coefficient of variation. The ranks of their consistency have also been depicted. The age records 0.49 coefficient of variation; the variable education recorded 0.50 coefficient of variation. The land holding got 0.42 coefficient of variation. The annual income recorded 0.65 coefficient of variation. The family size indicates 0.09 coefficient of variation. The social participation indicates 0.64 coefficient of variation. The extension contact of the respondent revealed 0.52 coefficient of variation. The other variable such as sources of information, progressiveness and risk bearing capacity indicates $0.72,0.89$ and 0.90 coefficient of variation respectively. From table-5 the variables as ranked according to their impactrick bearing capacity, progressiveness, source of information, annual income, social participation, extension contact, education, age, land holding, family size.These are discussed below.

Through this study it can be inferred that knowledge of recommended guava production practices is largely depend upon the socio-economic, social participation, source of information and psychological characteristics of guava grower. 


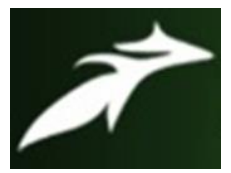

MOHAMMAD MONIS ANSARI et al, International Journal of Advances in Agricultural Science and Technology, Vol.7 Issue.12, December-2020, pg. 21-28

ISSN: 2348-1358

Impact Factor: 6.057

NAAS Rating: 3.77

Table-5 Distribution of the variables with reference to respondent profile:

\begin{tabular}{|c|c|c|}
\hline Socio-Economic Profile & Correlation Coefficient (r) & Rank \\
\hline Age & $0.49^{*}$ & 8 \\
\hline Education & $0.50^{*}$ & 7 \\
\hline Land Holding & $0.42^{*}$ & 4 \\
\hline Annual Income & $0.65^{*}$ & 10 \\
\hline Family Type & 0.095 (N.S) & 5 \\
\hline Social Participation & $0.64 *$ & 6 \\
\hline Extension Contact & $0.52^{*}$ & 3 \\
\hline Source of Information & $0.79 * *$ & 2 \\
\hline Progressiveness & $0.89^{* *}$ & 1 \\
\hline Risk Bearing Capacity & $0.90^{* *}$ & \\
\hline
\end{tabular}

**Strongly significant, *moderately significant, NS non-significant

\section{CONCLUSION}

It was concluded that the socio-economic profile of the respondents were medium level, it was also found that the knowledge level of the respondents were medium level because they've medium level of knowledge in their processing of different activities. The major association of knowledge and socio-economic status were Risk bearing capacity, Progressiveness, Source of information, Annual income and Social participation were strong positively correlated, that means improving of these independent variables there will be improvement in the knowledge too. Therefore the suggestions are that proper extension strategies, training programs and field demonstration should be provided on regular basis to improve the knowledge level of the Guava growers.

\section{REFERENCES}

[1]. A.N. Deshmukh, G. B. More, R. T. Katole and P. A. Hirulkar (2016).Knowledge of production technology of banana growers.Agriculture Update Volume 11,| Issue 3, | August, 2016, |250-254

[2]. Howal, A. A.; Khalache, P. G. and Sonawane, H. P. 2009. A study on attributes and constraints of the pomegranate cultivators of Solapur district, Agriculture Update, 4(3\&4): 282-284.

[3]. Kachare, V.S. 2012. Study on adoption gap in sweet orange production practices. M.Sc. (Agri.) Thesis (Unpublished), VasantraoNaikMarathwada Agricultural University, Parbhani.

[4]. Pandya, S. P.; Prajapati, M. R. and Thakar, K. P. 2014. Factor associated with adoption of date palm cultivation technology by the farmers. Gujarat Journal of Extension Education, 25(1): 49-51. 


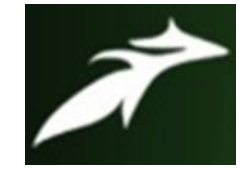

MOHAMMAD MONIS ANSARI et al, International Journal of Advances in Agricultural Science and Technology, Vol.7 Issue.12, December-2020, pg. 21-28

ISSN: 2348-1358 Impact Factor: 6.057 NAAS Rating: 3.77

[5]. Punia, A.; Goel, R. and Yadav, B. 2009. Knowledge and attitude of rural women about lemon products. Asian Journal of Home Science, 4(2): 333-336.

[6]. Singh B. P.; YadavR.N.; Mishra A. K.; Gupta V.; Raja M. M.; and Singh N. K. 2018 A Study of Socio-Economic Status of Guava Orchardists in Saharanpur District (Uttar Pradesh), India: International Journal of Current Microbiology and Applied SciencesISSN: 2319-7706 Volume 6 Number 8 (2017) pp. 1845-1849.

[7]. Yadav, B. C.; Choudhary, R. and Saran, P. L. 2013. Adoption of improved production technology of mandarin in Rajasthan, India: A review. African Journal of Agricultural Research, 8(49): 6590-6600. 